Article

\title{
Machinability Research of the Most Common Invasive Tree Species in Slovenia
}

\author{
Miran Merhar*(D), Dominika Gornik Bučar and Maks Merela \\ Department of Wood Science and Technology, Biotechnical Faculty, University of Ljubljana, 1000 Ljubljana, \\ Slovenia; Dominika.Gornik@bf.uni-lj.si (D.G.B.); Maks.Merela@bf.uni-lj.si (M.M.) \\ * Correspondence: Miran.Merhar@bf.uni-lj.si; Tel.: +38-613-203-629
}

Received: 15 June 2020; Accepted: 9 July 2020; Published: 12 July 2020

check for updates

\begin{abstract}
This article investigates the quality of the machining surface of the five most common invasive tree species in Slovenia, i.e., black locust (Robinia pseudoacacia L.), boxelder maple (Acer negundo L.), horse chestnut (Aesculus hippocastanum), honey locust (Gleditsia triacanthos) and tree of heaven (Ailanthus altissima). The machining tests were made according to the American Society for Testing and Materials (ASTM) D1666-17 standard, where the quality of the surfaces after planing, routing and turning were evaluated with visual assessment, and the area and profile roughness parameters were also determined on selected specimens. The results showed that boxelder maple, horse chestnut and honey locust can be machined very well in all the studied operations, with the best results in routing and a little less good by turning, whereas the tree of heaven had the best quality in planing, and the worst by turning. Among all studied tree species, the black locust had the worst quality in planing, but the quality at routing was very similar to other tested species. The research also showed that there is little or no significant relationship between the qualities of the various types of machining for tested tree species.
\end{abstract}

Keywords: machining; wood properties; surface quality; planing; routing; turning

\section{Introduction}

The presence of the invasive tree species in our environment is a fact and demands concern regarding their impact on the ecosystem properties and functions, since the invasion of alien species reduces local plant species diversity. In Slovenia, there are more than 180 different alien plant species identified, and approximately 40 of them are invasive. According to the latest research, approximately 25 species can be used for various purposes [1-4]. More than half of these species are woody and can be found as trees or shrubs [2,3,5]. Some of them were originally planted in parks and urban environments, but their growth eventually became uncontrolled, and nowadays they are considered as invasive species.

The usability of these species is not well known, and most of them are considered as undervalued and underutilized [6,7], while some of them are often used as biomass for energy production [8,9]. The basic information concerning anatomy, physical-mechanical properties, machinability, gluing properties and durability has to be provided to use these woods in the most appropriate way in new (high value) products and not only in traditionally wooden ones.

In the previous years, black locust wood (Robinia pseudoacacia L.) was included in the European subsidizing program of tree species cultivation. A large quantity of this species is therefore going to be harvested in the forthcoming years [10], and knowledge concerning the machining properties and processing parameters of these less (or not commonly) utilized wood species are going to be crucial for further utilization. 
As stated by Porankiewicz [11], not much attention has been paid so far to the study of the machinability of black locust, as an interesting wood species (recently used for parquet production), and the reason for that oversight might be the limited lumber supply of this species. Usta et al. [12] investigated the influence of a preparative process at a relatively early stage in the planing process of black locust and European oak (Quercus petraea (Mattu.) Lieble.) and concluded that the surface roughness decreases when the feed rate and cutting depth decreases, but further investigations need to fully elucidate the machinability of this species by examining different preparative parameters to optimize the planing process.

Réh [13] studied the usability of decorative veneer made from lesser known and lesser used hardwoods (black locust, black walnut, tree of heaven), stating that the lesser known (and used) hardwoods are suitable for application in the furniture industry since the quality of veneer does not differ from the commonly used veneers.

The quality of the wood surface can be characterized by surface irregularities or surface roughness. Besides machining, wood properties, structure and variability also affect the wood surface quality, and thus it is quite a demanding task to determine the wood surface roughness. Data on the quality of machining for a particular tree species is critical and should be available to every producer of wooden products. Many machining tests have recently been done for various exotic and non-traditional tree species [14-18]. In some cases, the quality of the machined surface can significantly affect the quality of the surface coatings as well as the quality of the bonded connection $[19,20]$. The fact is that the quality of the machined surface also depends on technological parameters of the machining, where optimal technological parameters such as feed rate and chip thickness exist for each tree species, as well as geometrical parameters of tools such as rake angle [21-24], but there is also a positive influence of wood thermal modification on the machining properties [25-27].

Several different methods that are used for checking the roughness of other materials have already been tested on wood surface. These are contact (stylus, pneumatic, acoustic emission) or non-contact (optical light sectioning and image analysis using video camera) methods [28,29]. The stylus instrument mechanically measures the surface profile in the selected area, but several researchers report that some significant parameters are still not fully explained and understood when analyzing the wood surface $[12,30,31]$. However, only gross comparison is possible using these methods, and specific information about the surface is not quantifiable [30]. There is no unique parameter that is able to describe the quality of the wood surface [32] and there is no commercially available device to be used specifically for wood surface measurement.

The presented research provides information about the basic and most commonly used machining tests under planing, routing and turning of the five most common invasive wood species in Slovenia, i.e., black locust (Robinia pseudoacacia L.), boxelder maple (Acer negundo L.), horse chestnut (Aesculus hippocastanum), honey locust (Gleditsia triacanthos) and tree of heaven (Ailanthus altissima). Testing is performed under different technological conditions, and statistical analysis of the dependence of the quality of machining under different conditions as well as the dependence between individual types of machining is made. The obtained data should form the basis for the usefulness of the tested tree species in every producer of wooden products.

\section{Materials and Methods}

The machining tests were made in accordance with the American Society for Testing and Materials (ASTM) D1666-17 [33] standard, where some parts of the standard were modified. The standard prescribes 50 samples for each tree species, but due to a lack of material, only 20 samples were taken for each tree species. For each tree species, four to five trees with the diameter from 20 to $40 \mathrm{~cm}$ were cut, and from each trunk, four to five boards were taken.

Clear boards (without visual defects) with the dimensions of: $1300 \times 135 \times 25 \mathrm{~mm}$, were conditioned at the temperature and relative humidity of $20{ }^{\circ} \mathrm{C}$ and $65 \%$ respectively, and then their density was determined. From each board, one sample was prepared for planing, one for routing and two samples 
for turning, according to the ASTM D1666 (2017) standard. After planning, routing and turning, visual examination of the machined surface was made by 3 experienced researchers with 20 to 30 years of experience. According to the surface quality, each surface was evaluated with the following grades: Grade 1—excellent, Grade 2—good, Grade 3-fair, Grade 4-poor and Grade 5-very poor. For each machining operation and each tree species, an average grade was determined, and according to the ASTM D1666 (2017) standard, the percentage of specimens with the Grades 1, 2 and 3 was calculated.

The significant differences of grades at different feed rates were verified by the analysis of variance (ANOVA) (F-test) analysis using SPSS software, where 5\% was taken for the level of significance ( $p$-value). In the case that the relationship between individual values could not be determined by the basic ANOVA analysis, an additional LSD (least significant difference) statistical analysis was performed with the same level of significance of $5 \%$.

\subsection{Planing}

For planing, the dimensions of the 20 samples for each species with radial or tangential texture were $900 \times 102 \times 19 \mathrm{~mm}$. Planing was performed by means of the thicknessing machine, using 4 freshly sharpened HSS (high speed steel) knives with the rake angle of $30^{\circ}$, revolution speed of $4500 \mathrm{rpm}$ and feeding speeds of 5, 8, 12 and $18 \mathrm{~m} / \mathrm{min}$, where the thickness of the cut amounted to $1.6 \mathrm{~mm}$. With these conditions, feed per tooth amounted to $0.28,0.44,0.67$ and $1 \mathrm{~mm}$. Half of the specimens were fed into the machine with the grain and half against the grain.

Since the knives were not jointed on the spindle, it was impossible to achieve that all the knives would be on the same cutting circle. In our case, one knife had a $0.01 \mathrm{~mm}$ bigger cutting diameter, which resulted in the single knife finish. Considering this, the knife marks were 1.1, 1.8, 2.7 and $4 \mathrm{~mm}$.

After planing, a visual examination for raised, fuzzy and torn grain was made. The percentage of specimens with the Grade 1 was determined, and the average grade for each tree species was calculated.

\subsection{Routing}

20 routing samples for each tree species with radial or tangential texture had the dimensions of $305 \times 76 \times 19 \mathrm{~mm}$. First, a preliminary roughing cut was made with the router to approximate the shape (Figure 1). Then, the second roughing cut was made to remove any damages made in the first cut, whereupon a final finishing cut was made, where the thickness of the cut was $1.6 \mathrm{~mm}$. The edge of the specimen was parallel for half of their length, while the remainder of the length was parabola (Figure 1). The spindle speed of the router and feed speed amounted to $8000 \mathrm{rpm}$ and $3000 \mathrm{~mm} / \mathrm{min}$ respectively, where the milling head had 2 knives.

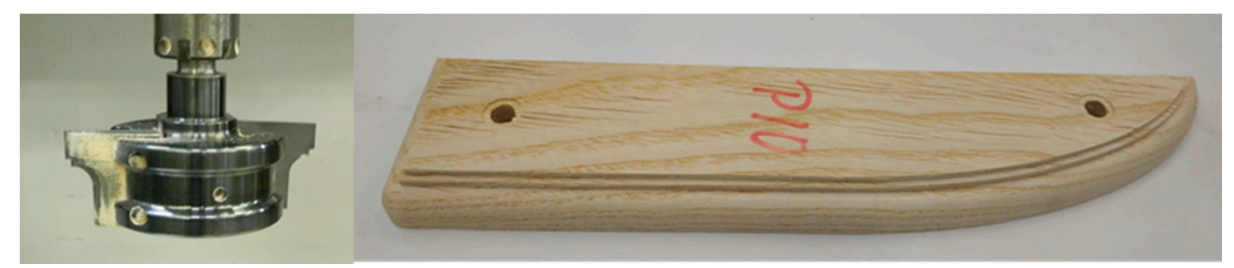

Figure 1. (Left)—Routing head with 2 tungsten carbide knives, (Right)—routing sample made of tree of heaven (Ailanthus altissima).

The side and end grain surfaces were graded for raised, fuzzy, chipped grain and roughness of end grain milling. The percentage of specimens with the Grades 1 and 2 was determined and the average grade for each tree species was calculated.

End grain routing is known as problematic because the surface quality is usually much lower than in the side grain routing, especially when the same routing cutter is used. For comparative purposes, one representative sample of end grain surface for a poor-quality surface and one for a good one for each tree species were taken for detailed surface laser examination. Their surfaces were measured with 
a Measuring Laser Microscope Olympus LEXT 3D OLS5000, where optical camera and laser scans were performed to evaluate surface roughness. To determine the area surface parameters, an area with small lumen diameters was selected, since lumens with high diameters can significantly influence the roughness parameter calculation as a quasi-chipped area. In each measured area, a representative profile for calculating the profile roughness parameters was also determined based on subjective assessment, where we also tried to avoid large lumen of the wood cells.

After the measurement, the following area roughness parameters were determined:

Sv-Absolute value of the height of the largest pit within the defined area.

$\mathrm{Sp}$-Height of the highest peak within the defined area.

St-Distance between the largest peak height value and the largest pit depth value within the defined area.

Profile roughness parameters were on the selected profile:

$\mathrm{Ra}$-Arithmetic mean of all deviations from the center line over the sampling path.

Rp-Maximum profile peak height along the sampling length.

Rv-Maximum profile valley depth along the sampling length.

Rt-Total height of profile: the distance between the maximum profile peak height and the maximum profile valley depth along the sampling length.

\subsection{Turning}

40 turning samples for each species were $127 \times 19 \times 19 \mathrm{~mm}$ in size (Figure 2), whereby the rotational speed of the specimens and feed rate of the blade was $3200 \mathrm{rpm}$ and $120 \mathrm{~mm} / \mathrm{min}$, respectively. First, a rough turning and then a fine turning were done, where the thickness of the cut at final turning was $2 \mathrm{~mm}$. The specimens were graded for fuzzy grain, roughness and torn grain at three locations, as shown in Figure 2, and the average value was calculated. The percentage of specimens with the Grades 1, 2 and 3 was determined and average grade for each tree species was calculated.

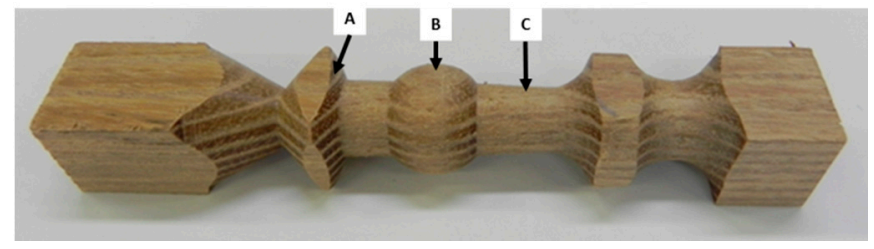

Figure 2. Specimen for turning test with locations A, B and C for assessment of the quality of turning, made of black locust (Robinia pseudoacacia L.).

\section{Results and Discussion}

Material average densities with standard deviations (SD) for tested tree species are shown in Table 1. The lowest density had horse chestnut with the average value of $495 \mathrm{~kg} / \mathrm{m}^{3}$ and standard deviation of $22 \mathrm{~kg} / \mathrm{m}^{3}$, while the highest average density had black locust with the value of $778 \mathrm{~kg} / \mathrm{m}^{3}$ and standard deviation of $54 \mathrm{~kg} / \mathrm{m}^{3}$.

Table 1. Material average densities and standard deviations (SD) for tested tree species.

\begin{tabular}{ccc}
\hline Tree Species & Density $\left(\mathbf{k g} / \mathbf{m}^{\mathbf{3}}\right)$ & SD $\left.\mathbf{( k g} / \mathbf{m}^{\mathbf{3}}\right)$ \\
\hline Boxelder Maple & 560 & 24 \\
Horse Chestnut & 495 & 22 \\
Tree of Heaven & 555 & 98 \\
Black Locust & 778 & 54 \\
Honey Locust & 705 & 50 \\
\hline
\end{tabular}




\subsection{Planing}

Figure 3 shows planing surfaces with evaluated grades 1 to 5 while Figure 4 shows the average grades with the standard deviation for each tree species for planing operation at different feeding speeds. It is obvious from Figure 4 that tree of heaven has the best grades in the range from 1.10 to 1.45 , while black locust has the worst grades with the average grade of 3.65 at the highest feeding speed. All species feature better grades at lower feeding speeds, and the surface quality is decreasing with increasing feeding speed, with the greatest difference in quality again shown by black locust.
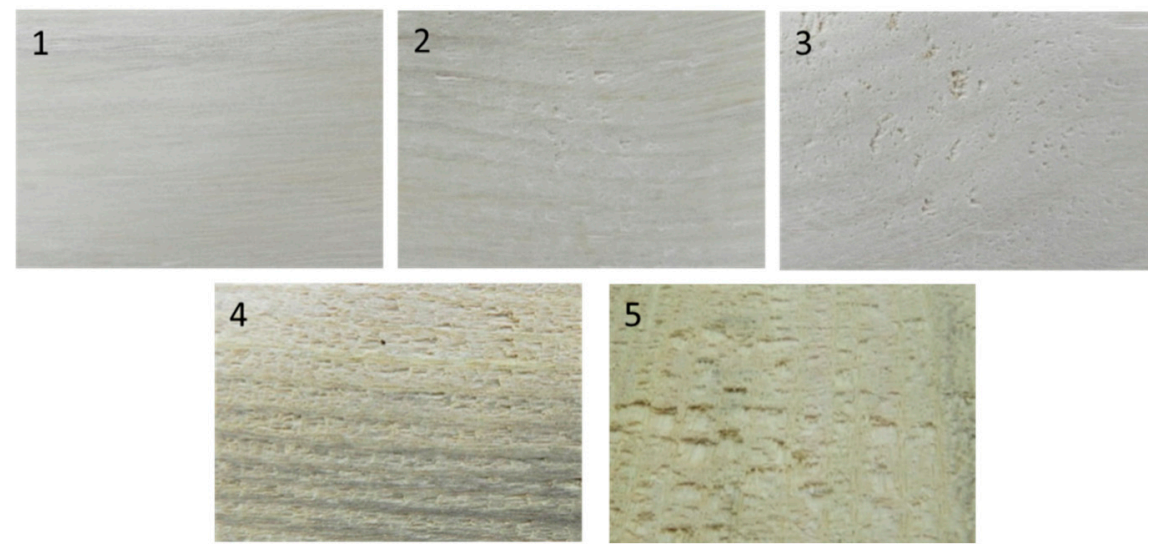

Figure 3. Planing surface quality—torn grain: Grades 1 to 5 (Grade 1 -excellent, Grade 2-good, Grade 3-fair, Grade 4-poor and Grade 5-very poor).

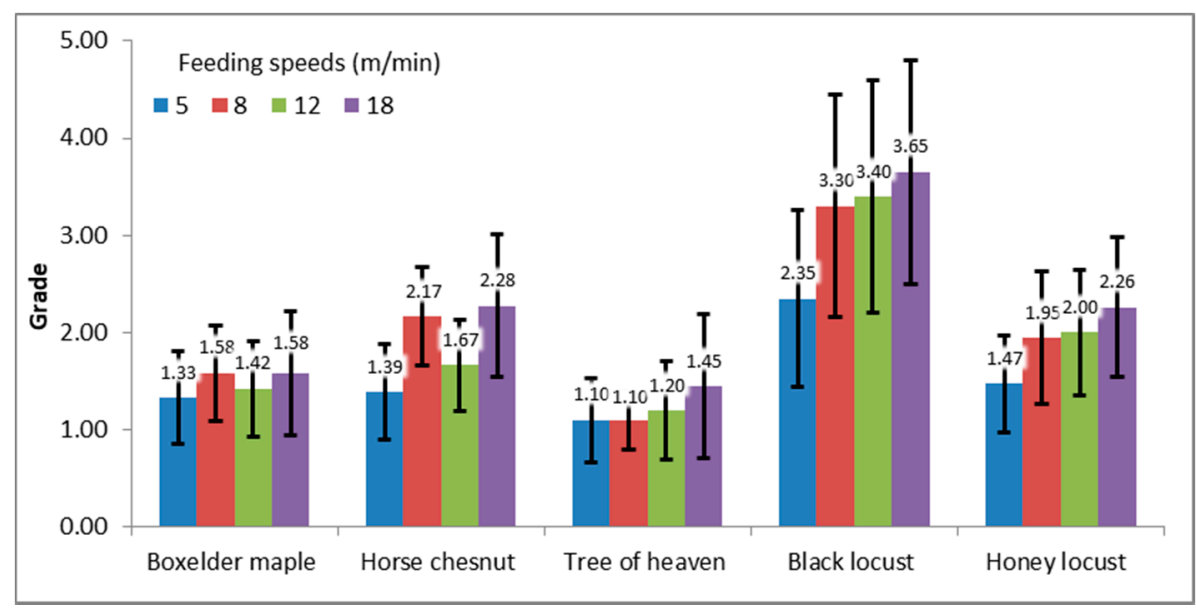

Figure 4. Average surface quality grades and standard deviations for tree species after planing at different feeding speeds.

Because the difference between the qualities at different feeding speeds varies at different tree species, an ANOVA analysis using SPSS software was performed to determine whether the grades for a particular tree species at different feeding speeds differ significantly. The results of this analysis are shown in the left part of Table 2. Based on the $p$-value where the limit was taken at $5 \%$, the table shows that the values differ significantly for horse chestnut, black locust and honey locust, where the $p$-values are written in bold. However, from the calculated values, we cannot distinguish between which combinations of feeding speeds there is a significant difference. To resolve this, the post hoc analysis using the LSD (least significant difference) method was performed, where the $p$-values between individual combinations of feeding speeds were calculated. The results are shown in Table 2, where the combinations of feeding speeds which are significantly different are also written in bold. 
Table 2. Statistical difference of the planing surface quality grades between feeding speeds for different tree species expressed by the $p$-value of the least significant difference (LSD) analysis of variance (ANOVA) analysis. The values in bold indicate a significant difference.

\begin{tabular}{|c|c|c|c|c|}
\hline \multirow{2}{*}{$\begin{array}{c}\text { Tree Species } \\
p \text {-Value (ANOVA) }\end{array}$} & \multirow{2}{*}{$\begin{array}{c}\text { Feeding Speed } \\
(\mathrm{m} / \mathrm{min})\end{array}$} & 8 & 12 & 18 \\
\hline & & \multicolumn{3}{|c|}{$p$-Value (LSD ANOVA) } \\
\hline \multirow{3}{*}{$\begin{array}{c}\text { Boxelder Maple } \\
0.61\end{array}$} & 5 & 0.27 & 0.71 & 0.27 \\
\hline & 8 & & 0.46 & 1.00 \\
\hline & 12 & & & 0.46 \\
\hline \multirow{3}{*}{$\begin{array}{c}\text { Horse Chestnut } \\
\mathbf{0 . 0 0}\end{array}$} & 5 & 0.00 & 0.15 & 0.00 \\
\hline & 8 & & 0.01 & 0.56 \\
\hline & 12 & & & 0.00 \\
\hline \multirow{3}{*}{$\begin{array}{c}\text { Tree of Heaven } \\
0.14\end{array}$} & 5 & 1.00 & 0.56 & 0.04 \\
\hline & 8 & & 0.56 & 0.04 \\
\hline & 12 & & & 0.14 \\
\hline \multirow{3}{*}{$\begin{array}{c}\text { Black Locust } \\
\mathbf{0 . 0 0}\end{array}$} & 5 & 0.01 & 0.01 & 0.00 \\
\hline & 8 & & 0.78 & 0.33 \\
\hline & 12 & & & 0.49 \\
\hline \multirow{3}{*}{$\begin{array}{c}\text { Honey Locust } \\
\mathbf{0 . 0 1}\end{array}$} & 5 & 0.03 & 0.02 & 0.00 \\
\hline & 8 & & 0.81 & 0.15 \\
\hline & 12 & & & 0.22 \\
\hline
\end{tabular}

According to the obtained analysis, we can conclude that boxelder maple can be planed equally well at all feeding speeds with the average grade from 1.33 to 1.58 , since according to the LSD ANOVA analysis, the grades between individual feeding speeds do not differ significantly. We can say similar for tree of heaven, which has the average grades from 1.10 to 1.45 , and has even better grades than boxelder maple, where the feeding speed has a significant negative impact only at higher values. However, the situation is just the opposite in the case of black locust and honey locust, with the average grades from 2.35 to 3.65 and from 1.47 to 2.26 respectively, where there is a significant difference only between the lowest and the rest of the feeding speeds, while there is no significant difference between the grades at higher speeds. The latter, together with lower grades, can be explained as the fact that these species are problematic for planing and very sensitive to the negative effect, which in our case is represented by higher feeding speed.

The ANOVA analysis was also performed between different tree species at feeding speeds of 5 and $18 \mathrm{~m} / \mathrm{min}$, as shown in Table 3 . The surface quality grades at feeding speed of $5 \mathrm{~m} / \mathrm{min}$ differ significantly between black locust and other species, and also between honey locust and tree of heaven. For other combinations, the values do not differ significantly, so it can be concluded with $95 \%$ of probability that tree species can be planed at the same quality at the feeding speed of $5 \mathrm{~m} / \mathrm{min}$. However, the situation is different at the feeding speed of $18 \mathrm{~m} / \mathrm{min}$, where the grades vary significantly among tree species everywhere, except between boxelder maple and tree of heaven and between honey locust and horse chestnut. The later analysis shows that the feeding speed at higher values influences the planing quality much more compared to the low values of feeding speed. 
Table 3. Statistical difference of the planing surface quality grades between the tree species at feeding speeds of $5 \mathrm{~m} / \mathrm{min}$ and $18 \mathrm{~m} / \mathrm{min}$ expressed by the $p$-value of the ANOVA analysis. The values in bold indicate a significant difference.

\begin{tabular}{|c|c|c|c|c|c|c|c|c|}
\hline & \multicolumn{2}{|c|}{ Horse Chestnut } & \multicolumn{2}{|c|}{ Tree of Heaven } & \multicolumn{2}{|c|}{ Black Locust } & \multicolumn{2}{|c|}{ Honey Locust } \\
\hline & $5 \mathrm{~m} / \mathrm{min}$ & $\begin{array}{c}18 \mathrm{~m} / \\
\mathrm{min}\end{array}$ & $5 \mathrm{~m} / \mathrm{min}$ & $\begin{array}{c}18 \mathrm{~m} / \\
\mathrm{min}\end{array}$ & $5 \mathrm{~m} / \mathrm{min}$ & $\begin{array}{c}18 \mathrm{~m} / \\
\mathrm{min}\end{array}$ & $5 \mathrm{~m} / \mathrm{min}$ & $\begin{array}{c}18 \mathrm{~m} / \\
\mathrm{min}\end{array}$ \\
\hline $\begin{array}{c}\text { Boxelder } \\
\text { Maple }\end{array}$ & 0.78 & 0.02 & 0.22 & 0.65 & 0.00 & 0.00 & 0.47 & 0.02 \\
\hline $\begin{array}{c}\text { Horse } \\
\text { Chestnut }\end{array}$ & & & 0.09 & 0.65 & 0.00 & 0.00 & 0.62 & 0.96 \\
\hline $\begin{array}{l}\text { Tree of } \\
\text { Heaven }\end{array}$ & & & & & 0.00 & 0.00 & 0.03 & 0.00 \\
\hline $\begin{array}{c}\text { Black } \\
\text { Locust }\end{array}$ & & & & & & & 0.00 & 0.00 \\
\hline
\end{tabular}

\subsection{Routing}

The average grades for side and end grain routing together with the standard deviations for each tree species are presented in Figure 5. Boxelder maple has the best grades with the average grade of 1.08 and 1.22 for side and end grain respectively, and horse chestnut with the average grade of 1.04 and 1.40 for side and end grain respectively, while tree of heaven has the worst grades with the average grade of 1.73 and 1.88 and also the highest standard deviation. An ANOVA analysis has shown a significant difference in surface quality between the side and end grain routing only in the case of tree of heaven, as shown in Table 4, while for other species, there is no significant difference between the directions of routing.

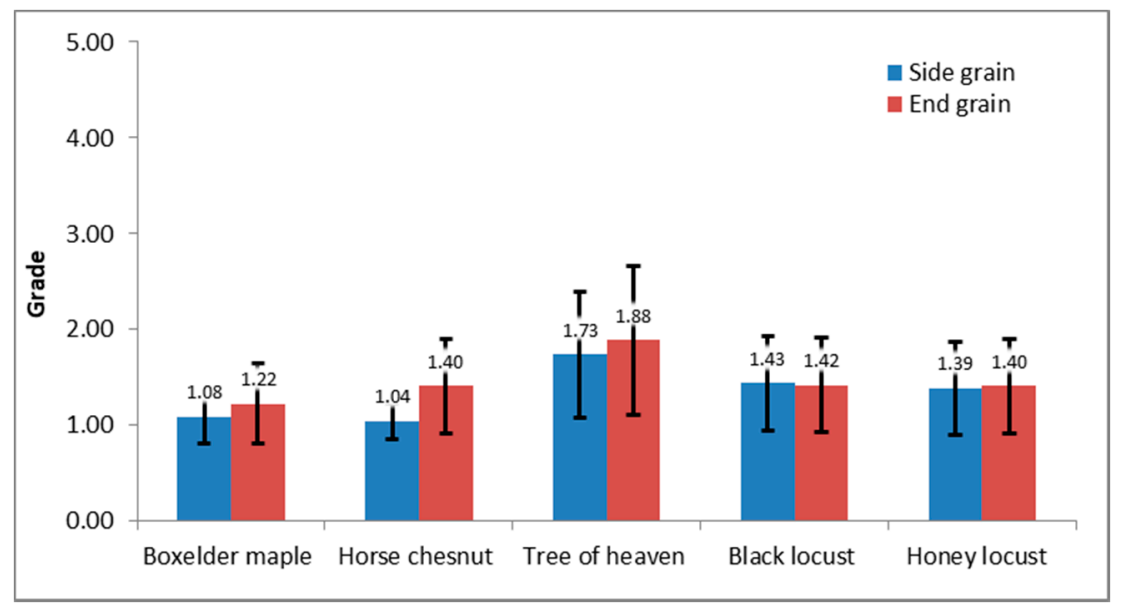

Figure 5. Average surface quality grades and standard deviations for tree species at side and end grain routing.

Table 4. Statistical difference of the routing surface quality grades between side and end grain expressed by the $p$-value of the ANOVA analysis. The values in bold indicate a significant difference.

\begin{tabular}{ccccc}
\hline Boxelder Maple & Horse Chestnut & Tree of Heaven & Black Locust & Honey Locust \\
\hline 0.75 & 0.55 & $\mathbf{0 . 0 1}$ & 0.06 & 0.13 \\
\hline
\end{tabular}


For each sample, the total average value from side and end grain routing grades were calculated and verified with the ANOVA analysis to check whether the grades between each tree species differ significantly. The results are shown in Table 5 where the cells with significant difference are shown in bold. The values do not differ significantly between boxelder maple and horse chestnut and between honey locust, horse chestnut and black locust, while the grades among other tree species differ significantly.

Table 5. Statistical difference of the routing surface quality grades between different tree species expressed by the $p$-value of the ANOVA analysis. The values in bold indicate a significant difference.

\begin{tabular}{ccccc}
\hline & Horse Chestnut & Tree of Heaven & Black Locust & Honey Locust \\
\hline Boxelder Maple & 0.51 & $\mathbf{0 . 0 0}$ & $\mathbf{0 . 0 1}$ & $\mathbf{0 . 0 2}$ \\
Horse Chestnut & & $\mathbf{0 . 0 0}$ & $\mathbf{0 . 0 1}$ & 0.05 \\
Tree of Heaven & & & $\mathbf{0 . 0 0}$ & 0.00 \\
Black Locust & & & 0.55 \\
\hline
\end{tabular}

Figure 6 shows the scanned end grain areas and roughness profiles of individual tested tree species, one for the best surface (designated as good surface) and one for the worst surface (designated as bad surface). Comparison of the roughness profiles of good surfaces reveals great differences between tree species, where honey locust has the smoothest line and horse chestnut has the roughest. Similar results are obtained from profile roughness parameters (Figure 7), where tree of heaven has the worst values for both area and profile roughness parameters, similar to the visual assessment grades shown in Figure 5.

Based on the profile roughness parameters (Figure 7), black locust and honey locust have the lowest values while boxelder maple and horse chestnut have the lowest average grades from visual assessment (Figure 5). This difference could be interpreted in a way that boxelder maple and horse chestnut, on average, can be end grain routed with better quality, but if we take a good sample of boxelder maple and horse chestnut and compare them with a good sample of black locust and honey locust, the latter will have smoother surfaces than the first one.

\subsection{Turning}

The turning average grades determined on surfaces A, B and C (Figure 2), together with standard deviations, are shown in Figure 8, while the results of the ANOVA analysis between the different tree species are shown in Table 6.

Table 6. Statistical difference of the turning surface quality grades between different tree species expressed by the $p$-value of the ANOVA analysis. The values in bold indicate a significant difference.

\begin{tabular}{ccccc}
\hline & Horse Chestnut & Tree of Heaven & Black Locust & Honey Locust \\
\hline Boxelder Maple & $\mathbf{0 . 0 0}$ & 0.28 & $\mathbf{0 . 0 1}$ & $\mathbf{0 . 0 0}$ \\
Horse Chestnut & & $\mathbf{0 . 0 0}$ & 0.55 & 0.65 \\
Tree of Heaven & & & $\mathbf{0 . 0 0}$ & $\mathbf{0 . 0 0}$ \\
Black Locust & & & & 0.29 \\
\hline
\end{tabular}



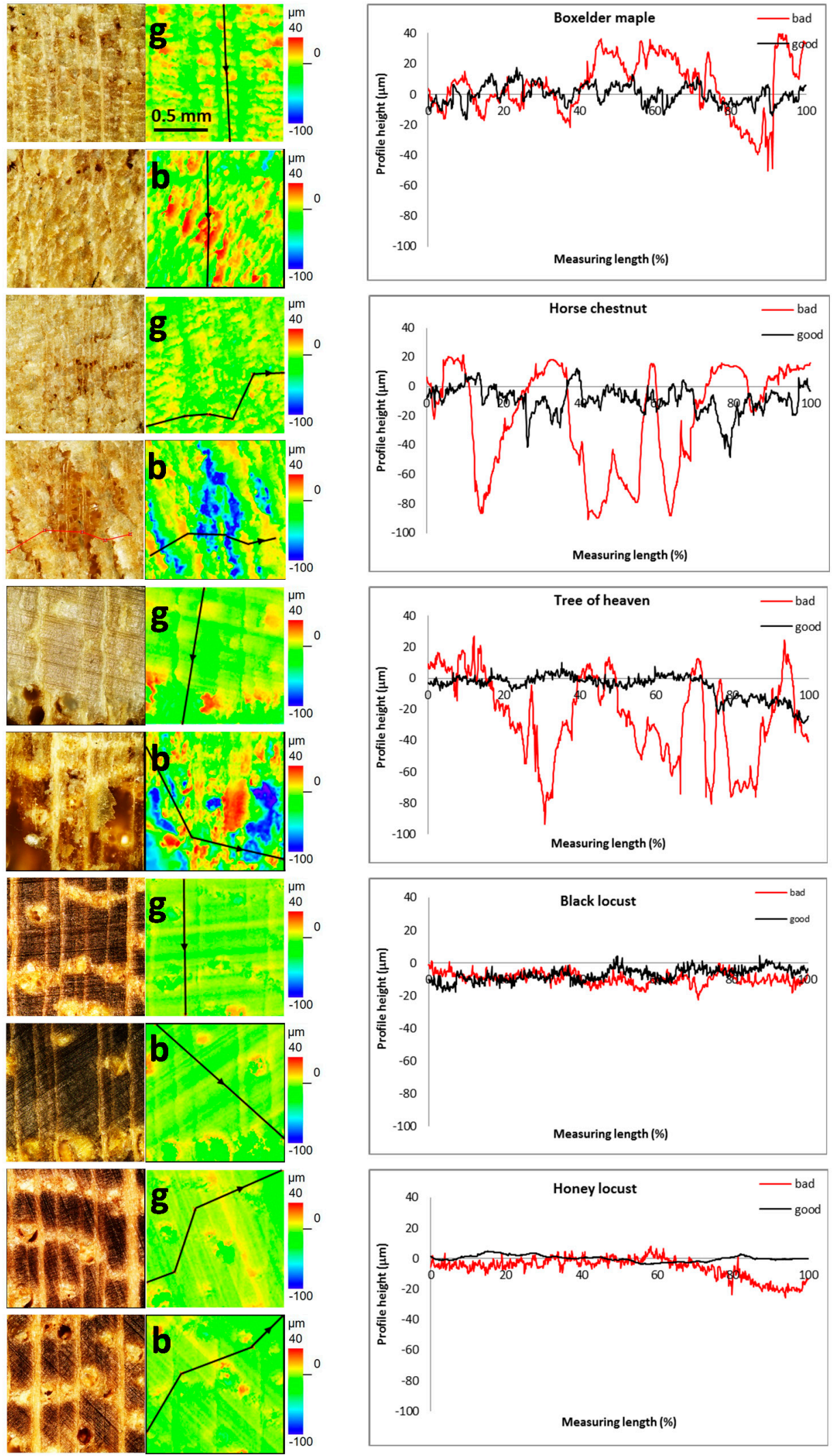

Figure 6. Areas and profile measurements done by a laser scanning microscopy of all analyzed species: $\mathrm{g}$-good surface, $\mathrm{b}$ - bad surface. Black lines on area measurements designate the profile measurements. 


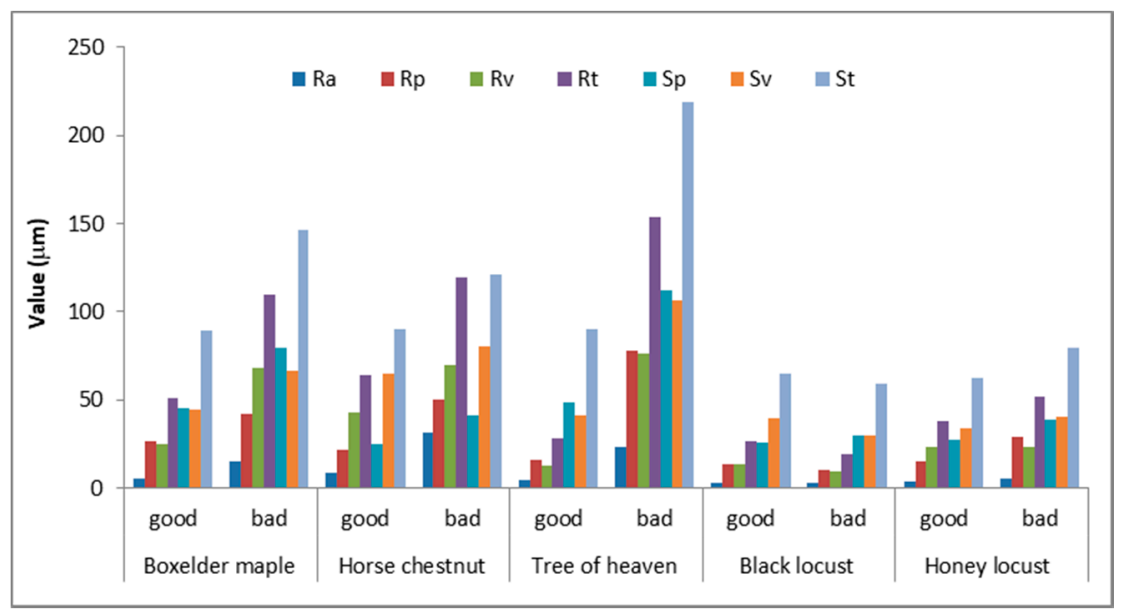

Figure 7. Area and profile roughness parameters for different tree species. "Bad" and "good" designation represents the best and the worst quality surface, respectively. Ra-arithmetic mean of all deviations from the center line over the sampling path, Rp-maximum profile peak height along the sampling length, Rv-maximum profile valley depth along the sampling length, Rt - total height of profile, $\mathrm{Sp}$ - height of the highest peak within the defined area, $\mathrm{Sv}$-absolute value of the height of the largest pit within the defined area, St-distance between the largest peak height value and the largest pit depth value within the defined area.

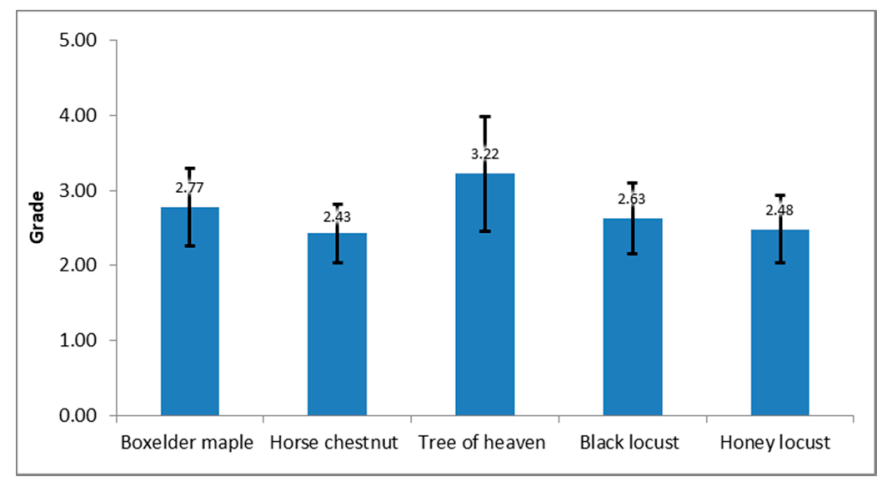

Figure 8. Average surface quality grades with standard deviations after turning.

It is clear from Figure 8 that tree of heaven has the worst grades with the grade of 3.22, while horse chestnut has the best grades with the value of 2.43 , to be followed by other tree species. On the basis of Table 6, it can be stated that the turning quality grades of horse chestnut, black locust and honey locust do not differ significantly from each other.

\subsection{Base Comparison Results}

Table 7 presents the results as a base comparison of different species on the percentage of Grades 1, 2 or 3 . The table shows a similar situation as described above under specific machining operations, but there may be a difference in some cases, such as in turning, where boxelder maple features a higher percentage of samples with fair to excellent grades than a honey locust, but has a worse average grade. The reason is that it can have a larger number of samples with a grade of 1 to 3, but also a few samples with higher grades, which increase the average grade. 
Table 7. Base comparison of the surface quality grades for different machining operations and tree species.

\begin{tabular}{|c|c|c|c|c|}
\hline & \multicolumn{2}{|c|}{ Planing } & \multirow{2}{*}{$\begin{array}{c}\text { Routing } \\
\begin{array}{c}\text { Good to Excellent } \\
(\%)\end{array}\end{array}$} & \multirow{2}{*}{$\begin{array}{c}\text { Turning } \\
\text { Fair to Excellent } \\
(\%)\end{array}$} \\
\hline & Knife Marks (mm) & Defect Free (\%) & & \\
\hline \multirow{4}{*}{ Boxelder Maple } & 1.1 & 67 & \multirow{4}{*}{100} & \multirow{4}{*}{79} \\
\hline & 1.8 & 42 & & \\
\hline & 2.7 & 58 & & \\
\hline & 4 & 50 & & \\
\hline \multirow{4}{*}{ Horse Chestnut } & 1.1 & 44 & \multirow{4}{*}{100} & \multirow{4}{*}{100} \\
\hline & 1.8 & 6 & & \\
\hline & 2.7 & 22 & & \\
\hline & 4 & 17 & & \\
\hline \multirow{4}{*}{ Tree of Heaven } & 1.1 & 70 & \multirow{4}{*}{45} & \multirow{4}{*}{26} \\
\hline & 1.8 & 75 & & \\
\hline & 2.7 & 75 & & \\
\hline & 4 & 65 & & \\
\hline \multirow{4}{*}{ Black Locust } & 1.1 & 20 & \multirow{4}{*}{100} & \multirow{4}{*}{60} \\
\hline & 1.8 & 10 & & \\
\hline & 2.7 & 10 & & \\
\hline & 4 & 10 & & \\
\hline \multirow{4}{*}{ Honey Locust } & 1.1 & 42 & \multirow{4}{*}{100} & \multirow{4}{*}{63} \\
\hline & 1.8 & 26 & & \\
\hline & 2.7 & 21 & & \\
\hline & 4 & 11 & & \\
\hline
\end{tabular}

\section{Conclusions}

The research carried out determined the machinability of the most common woody, non-native invasive tree species in Slovenia. Our findings support that some tree species can be very well machined, especially in specific machining operations, while others are worse. Similarly, there are differences in the surface quality produced by different machining operations in the same tree species. Thus, based on the visual grading of surface quality, it can be concluded for boxelder maple, horse chestnut and honey locust that they can be machined very well in all operations that have been studied, with the best results in routing and a little less in turning. The results are slightly different in the case of tree of heaven, which had, among all the studied tree species, the best quality in planing but the worst in turning. In the case of machining black locust, it had the worst quality in planing, while the quality for routing was very similar to other tree species.

The research carried out also showed that there is no significant relationship between the qualities of the various types of machining, which means that if, for example, machining properties for turning are required, it is necessary to carry out the turning test, as they cannot be concluded from the quality of the planing of the same tree species, because a particular tree species can be very well planed and poorly turned, and, of course, also vice versa.

The obtained results form the basis for the usefulness of the tested tree species, and as such, should be available to every producer of wooden products. Based on this data, the producer can decide which tree species will be used for certain products. 
Author Contributions: M.M. (Miran Merhar) designed experiments. M.M. (Miran Merhar), D.G.B. and M.M. (Maks Merela) performed the experiments. M.M. (Miran Merhar) analyzed the results and wrote the original draft. All authors reviewed and edited the manuscript and agreed to the published version of the manuscript.

Funding: The research was supported by APPLAUSE (UIA02-228) project, co-financed by the European Regional Development Fund through the Urban Innovative Actions Initiative (www.ljubljana.si/en/applause/), and additionally supported by the Programs P2-0182 and P4-0015, co-financed by the Slovenian Research Agency.

Acknowledgments: The authors wish to thank Jože Planinšič, Luka Krže, Angela Balzano and Drago Vidic for their immense help with sample preparation.

Conflicts of Interest: The authors declare no conflict of interest.

\section{References}

1. Merela, M.; Balzano, A.; Thaler, N.; Plavčak, D. Optimal Surface Preparation for Wood Anatomy Research of Invasive Species by Scanning Electron Microscopy. Drv. Ind. 2020, 71, 117-127. [CrossRef]

2. Plavčak, D.; Gorišek, Ž.; Straže, A.; Merela, M. Drying characteristics of wood of invasive tree species growing in an urban environment. Les/Wood 2019, 68, 31-43. [CrossRef]

3. Plavčak, D.; Gorišek, Ž.; Straže, A.; Merela, M. Properties and usability of Chinese sumac (Ailanthus altissima). In Proceedings of the First International Conference, Nature in Southern and Eastern Europe NISEE 2018, Sarajevo, Bosnia and Herzegovina, 26-30 September 2018.

4. Merela, M.; Oven, P.; Poljanšek, I.; Vek, V.; Merhar, M.; Gornik Bučar, D.; Kariž, M.; Šega, B.; Šernek, M.; Straže, A.; et al. Tujerodne invazivne rastline-Njihova analiza in uporaba. In Proceedings of the Klimatske Spremembe in Gozd, Ljubljana, Slovenia, 13-15 June 2019; pp. 13-19.

5. Plavčak, D.; Gorišek, Z.; Straže, A.; Merela, M. Drying characteristics of sapwood, discoloured wood and infected wood of box elder (Acer negundo L). In Proceedings of the 8th Hardwood Conference with Special Focus on New Aspects on Hardwood Utilization-From Science to Technology, Sopron, Hungary, 25-26 October 2018; pp. 76-77.

6. Grosser, D. Das Holz der Rosskastanie-Eigenschaften und Verwendung. Available online: https://www.lwf.bayern.de/mam/cms04/forsttechnik-holz/dateien/w48_das_holz_rosskastanie_eige nschaften_verwendung_gesch.pdf (accessed on 10 May 2020).

7. Zerbe, J.I. Basic properties of undervalued hardwoods. In Undervalued Hardwoods for Engineered Materials and Components; Ross, J.R., Erickson, J.R., Eds.; Forest Products Society: Madison, WI, USA, 2005; pp. 15-19.

8. Modryk, K. Quality Assessment for Briquettes made from Biomass from Maple (Acer negundo L.) and Black Locust (Robinia pseudoacacia L.). Agric. Eng. 2011, 132, 115-121.

9. Gornik Bučar, D.; Gospodarič, B.; Smolnikar, P.; Stare, D.; Kranjc, N.; Prislan, P. Invasive species as raw material for pellets production. In Implemenatation of Wood Science in Woodworking Sector: Proceedings: 70th Anniversary of Drona Industrija Journal; University of Zagreb: Zagreb, Croatia, 2019; pp. 61-68.

10. Vasiliki, K.; Ioannis, B. Bondability Of Black Locust (Robinia pseudoacacia) And Beech Wood (Fagus sylvatica) With Polyvinyl Acetate And Polyurethane Adhesives. Maderas-Cienc. Y Tecnol. 2017, 19, 87-94. [CrossRef]

11. Porankiewicz, B.; Dolata, A.; Wieloch, G. Cutting Force During The Turning Of Wood From Black Locust. Bioresources 2008, 3, 745-757.

12. Usta, I.; Demirci, S.; Kilic, Y. Comparison of surface roughness of Locust acacia (Robinia pseudoacacia L.) and European oak (Quercus petraea (Mattu.) Lieble.) in terms of the preparative process by planing. Build. Environ. 2007, 42, 2988-2992. [CrossRef]

13. Reh, R. Utilization of lesser known and lesser used hardwoods for decorative veneers purposes. In Proceedings of the 8th Hardwood Conference with Special Focus on New Aspects on Hardwood Utilization-from Science to Technology, Sopron, Hungary, 25-26 October 2018; pp. 134-135.

14. Belleville, B.; Iru, R.; Tsiritsi, C.; Ozarska, B. Planing characteristics of Papua New Guinea timber species from plantations and regrowth forests. Eur. J. Wood Wood Prod. 2020, 78, 343-349. [CrossRef]

15. Cárdenas, M.M.; Juízo, C.G.F.; Guillén, N.B.; Mora, H.E.G.; Klitzke, R.J.; da Rocha, M.P. Surface quality of Peruvian Amazon woods submitted for planning and sanding. Floresta 2019, 49, 671-680. [CrossRef]

16. Gupta, S.; Singh, C.P.; Kishan-Kumar, V.S.; Shukla, S. Machining properties of Melia dubia wood. Maderas Cienc. Y Tecnol. 2019, 21, 197-208. [CrossRef] 
17. Kotlarewski, N.J.; Derikvand, M.; Lee, M.; Whiteroad, I. Machinability study of australia's dominate plantation timber resources. Forests 2019, 10, 805. [CrossRef]

18. Sofuoglu, S.D.; Kurtoglu, A. Some machining properties of 4 wood species grown in Turkey. Turk. J. Agric. For. 2014, 38, 420-427. [CrossRef]

19. Li, W.; Zhang, Z.; He, S.; Zhou, G.; Mei, C. The effect of lathe checks on the mechanical performance of LVL. Eur. J. Wood Wood Prod. 2020, 78, 545-554. [CrossRef]

20. Ugulino, B.; Hernandez, R.E. Assessment of surface properties and solvent-borne coating performance of red oak wood produced by peripheral planing. Eur. J. Wood Wood Prod. 2017, 75, 581-593. [CrossRef]

21. Dobrzynski, M.; Orlowski, K.A.; Biskup, M. Comparison of surface quality and tool-life of glulam window elements after planing. Drv. Ind. 2019, 70,7-18. [CrossRef]

22. Häusler, A.; Werkle, K.T.; Maier, W.; Möhring, H.C. Design of lightweight cutting tools. Int. J. Autom. Technol. 2020, 14, 326-335. [CrossRef]

23. Pinkowski, G.; Szymanski, W.; Krauss, A.; Stefanowski, S. Effect of sharpness angle and feeding speed on the surface roughness during milling of various wood species. Bioresources 2019, 13, 6952-6962. [CrossRef]

24. Siklienka, M.; Janda, P.; Jankech, A. The Influence Of Milling Heads On The Quality Of Created Surface. Acta Fac. Xylol. Zvolen 2016, 58, 81-88. [CrossRef]

25. De Moura, L.F.; Brito, J.O.; Nolasco, A.M.; Uliana, L.R. Effect of thermal rectification on machinability of Eucalyptus grandis and Pinus caribaea var. hondurensis woods. Eur. J. Wood Wood Prod. 2011, 69, 641-648. [CrossRef]

26. Merhar, M.; Šega, B.; Gornik, B.D. The influence of thermal modification on the machining properties of beech wood. Les/Wood 2019, 68, 15-24. [CrossRef]

27. Sandak, J.; Goli, G.; Cetera, P.; Sandak, A.; Cavalli, A.; Todaro, L. Machinability of Minor Wooden Species before and after Modification with Thermo-Vacuum Technology. Materials 2017, 10, 121. [CrossRef]

28. Coelho, C.L.; Carvalho, L.M.H.; Martins, J.M.; Costa, C.A.V.; Masson, D.; Méausoone, P.J. Method for evaluating the influence of wood machining conditions on the objective characterization and subjective perception of a finished surface. Wood Sci. Technol. 2008, 42, 181-195. [CrossRef]

29. Lemaster, R.L. The use of an optical profilometer to monitor product quality in wood and woodbased products. In Proceedings of the Sanding and Sawing Seminar, Portland, OR, USA, 21-22 September 1995; Charlotte, NC, USA, 14-15 November 1995. pp. 33-42.

30. Hendarto, B.; Shayan, E.; Ozarska, B.; Carr, R. Analysis of roughness of a sanded wood surface. Int. J. Adv. Manuf. Technol. 2006, 28, 775-780. [CrossRef]

31. Lemaster, R.L.; Taylor, J.B. High-speed surface assessment of wood and wood-based composites. In Proceedings of the 14th Wood Machining Seminar, Paris, France, 12-19 September 1999; pp. 479-488.

32. Triboulot, P.; Kremer, P.; Martin, P.; Leban, J.M. Planing Of Norway Spruce With Very Varied Ring Width. Holz Als Roh-Und Werkst. 1991, 49, 181-184. [CrossRef]

33. ASTM. ASTM D1666 Standard Test Methods for Conducting Machining Tests of Wood and Wood Based Materials; ASTM: Philadelphia, PA, USA, 2017.

(C) 2020 by the authors. Licensee MDPI, Basel, Switzerland. This article is an open access article distributed under the terms and conditions of the Creative Commons Attribution (CC BY) license (http://creativecommons.org/licenses/by/4.0/). 